 \\ JDss | Journal of Development and Social Sciences WWW.Jdss.org, ,1k \\ RESEARCH PAPER
}

\section{Modi and Kashmir: Future Prospects}

\author{
${ }^{1}$ Munazzah Bukhari* $\quad{ }^{2}$ Dr. Tayyaba Muzammal ${ }^{3}$ Dr. Muhammad Ijaz Latif
}

1. Research Scholar, South Asian Study Centre, University of the Punjab, Lahore, Punjab, Pakistan

2. Assistant Professor, Department of Political Science and IR, GC Women University, Faisalabad, Punjab, Pakistan

3. Professor/Chairman, Department of International Relations, The Islamia University of Bahawalpur, Punjab, Pakistan

\begin{tabular}{|c|c|}
\hline PAPER INFO & ABSTRACT \\
\hline $\begin{array}{l}\text { Received: } \\
\text { February 28, } 2021 \\
\text { Accepted: } \\
\text { June 10, 2021 } \\
\text { Online: } \\
\text { June 20, } 2021\end{array}$ & $\begin{array}{l}\text { The study explores that even in the } 21^{\text {st }} \text { century Kashmir is deprive } \\
\text { from freedom under government of of Nraendra Modi. Since } 1947 \\
\text { there is a stark restriction on basic human freedoms and blood-letting } \\
\text { continues in the Kashmir Valley which has undermined the peace } \\
\text { process and prosperity of the region. Kashmir under the partition plan }\end{array}$ \\
\hline $\begin{array}{l}\text { Keywords: } \\
\text { Authoritarian } \\
\text { Rule, } \\
\text { BJP Government, } \\
\text { Future Prospects, } \\
\text { Kashmir and } \\
\text { Fascism, } \\
\text { Modi and Kashmir }\end{array}$ & $\begin{array}{l}\text { of always a hurdle in the way of Kashmir's right of self-determination. } \\
\text { Hindutva project of Modi and his party is humiliating Muslims in } \\
\text { Kashmir. A shameless and disrespectful boldness of Modi led BJP } \\
\text { government and its violent attack on federalism and democracy } \\
\text { further stir up alienation among Kashmiri people instead of fostering } \\
\text { sense of belonging to the Indian union. Whatever political, physical } \\
\text { and psychological mark has to be forced to endure by India and }\end{array}$ \\
\hline $\begin{array}{l}\text { *Corresponding } \\
\text { Author: }\end{array}$ & $\begin{array}{l}\text { Pakistan over Kashmir due to stubborn attitude and authoritarian rule } \\
\text { of Indian government, it is Kashmir that on every occasion suffered } \\
\text { more. The study is based on qualitative methods and examines the } \\
\text { impacts of Modi Nationalism in Kashmir that how it is making the } \\
\text { future of south Asian region darker. }\end{array}$ \\
\hline
\end{tabular}

Introduction

India which is considered as world's largest democracy is ruling without justice and practicing the fascist ideology under the leadership of Modi in Kashmir. It is totally against the democratic principles of democracy. Once a Kashmiri protestor in Srinagar put these words about Indian government in his poster that 'Democracy without justice= Demon Crazy'. (Roy, 2009, p.xi).BJP does not have the mandate of people and ruthlessly promoting his fascist agenda in Kashmir. Sang Privar which is Hindu, political and cultural organization and joint family of BJP, RSS, Bajrang Dal and VHP. This organization provides all of them basis for promoting Hindu Nationalism allover in India and in Kashmir. Sang Parivar administer under a mandate of communal hatred. It has been injecting a poison into the bloodstream of civil society by propagating young minds with religious hatred and anti-Muslims feelings. (Roy, 2009). Hundreds of RSS Shakhs across India is doing such activities to fulfill its fascist agenda. Rashtriya Swayamsevak Sang (RSS) is moral and cultural association of the BJP (Roy, 2009). It was founded in 1925 by Dr. K. B. Hedgewar. 
He had great inspiration from Benito Mussolini and idealized her ideology of Italian fascism. For him Hitler too was an inspirational figure. So, he opted ideology of Hindutva for promoting Hindu Nationalism. RSS is now projecting Hedgewear ideology of Hindu Nationalism without caring the religious sentiments of other communities. BJP who is the follower of RSS and it has close link with its Hindu militant organization which is creating unrest in Kashmir by promoting Hindutva ruthlessly. (Roy, 2009, p.146).There are few quotes given in the bible of RSS that exposed mentality and fascist ideology of Modi in Indian Occupied Kashmir. RSS bible named as 'We, Our, Nationhood 'well-defined by M.S Golwalker who succeeded Dr. Hedgewar as head of the RSS stated that:

"Ever since that evil day, when Moslems first landed in Hindustan, right up to the present moment, the Hindu Nation had been gallantly fighting on to take on these despoilers. The race spirit has been awakening" (Roy, 2009, p.147).

It is a significant work that helps us to understand the fundamental beliefs of the Hindu nationalist right in India. Golwalkar concludes his argument that a 'Nation is a compound of five distinct factors fused into one indissoluble whole... Geographical (country), Racial (Race), Religious (Religion), Cultural (Culture) and Linguistic (language)'. He believes that religion is the integral part of nationality, and that 'with us, every action in life, individual, social or political, is a command of Religion'. Culture and politics are not separate from religion. He excludes everything which is not 'Hindu' from being a part of the national culture. This approach is mirrored in the actions of RSS/BJP even today. For example, they call to change the name of roads and cities whose names contain a nonHindu influence (Masood, et. al. 2020) (Pegajtraju, 2021).He openly states that "all those, who fall outside the five-fold limits of that idea, can have no place in the national life, unless they abandon their differences, adopt the religion, culture and language of the Nation and completely merge themselves in the National Race". In his opinion, minorities have to integrate themselves into the National Race "by losing all consciousness of their separate existence, forgetting their foreign origin. If they do not do so, they live merely as outsiders'; they 'may stay in the country, wholly subordinated to the Hindu Nation, claiming nothing, deserving no privileges, far less any preferential treatment - not even citizen's rights'. (Pegajtraju, 2021).Today, if we see these words are not only the expressions of extremism but seems closer to being true because of the plan of BJP for the enactment of Reorganization Act of Oct 31, 2019 and the Citizenship Amendment bill. This is clearly shows that the RSS/BJP is completely following all those views which are expressed in the bible of RSS.

Communal government of Modi is doing every possible effort to convert India into a Hindu Rashtara since past and also suppressing every voice that raises against its brutal policies. On August 05, 2019 BJP government's illegitimate actions in Indian illegally occupied Jammu and Kashmir under the leadership of Modi have again proved that India is a fascist state.

“Fascist Indian government is hell bent upon converting IIOJK's Muslim majority into a minority"(Kashmir Media Service, 2021).

Fascist ideology of Modi is the biggest danger for South Asia's peace and stability. 
Professor Prabhat Patnaik who was left-wing intellectual, formerly working at Cambridge University and now at Jawaharlal Nehru University, views that:

"The Hindutva movement as it has emerged is, almost in a classical sense, Fascist in its ideology, Fascist in its class support, Fascist in its methods, and Fascist in its programme" (Hussain, 2019).

One of the main Fascist agenda is the racial superiority through the expansion of territory to restore its magnificent historical kingdom. To enhance the military power by the production of military weapons for victory in war by Hitler was significant prove of this idea that the 'Master race' could establish hegemony over neighboring countries and 'inferior races'. The annexation of Indian Occupied Kashmir by Narendra Modi shows that he is full supporter of Hitler's Fascism and its propagation. It is explicitly stated in the Manifesto of BJP's document of 2019 that:

"We reiterate our position since the time of the Jan Sangh to the abrogation of Article 370."(Hussain, 2019).

According to some analysts, the annexation of Indian Occupied Kashmir by BJP government is only the first step to fulfill the project of Hindutva. The next step towards the accomplishment of Hindutva project is to merge Azad Kashmir and Gilgit-Baltistan with Bharat Mata. Their intention of further expansion of territory was made clear by the speech of their Home Minister Amit Shahin the Indian parliament. He stated that:

“PoK also falls within Kashmir. We will give up our lives for it”(Hussain, 2019).

Once again after Modi's policies Kashmir has been caught up in the political and nationalist winds.

\section{Modi's Fascist Ideology and Prosecution of Cruel Laws}

Under Prime Minister, Narendra ModiIndia has become a fascist state. As a member of extremist Hindu organization named as (RSS) Rashtriya Swayamsevak Sangh, he is following the Nazi-ideology in Kashmir which has serious implications in future. According to research report of Kashmir Media Service:

"Modi-led communal government was leaving no stone unturned to convert India into a Hindu Rashtara and suppressing every voice that criticizes its cruel policies".(Kashmir Media Service, 2021).

Modi is working for Akhand Bharat which means "undivided India" to keep the purity of the land of Indian subcontinent by restoring it towards Hinduism under Hindutva project. Therefore, he is taking steps by passing cruel laws to covert Kashmir into the land of Hindu and trying to make it permanent part of Indian state by ignoring the mandate of people.India is not willing to give the right of Self-determination to the people of Kashmir and ruthlessly promoting its fascist ideology (Hussain, 2019).

\section{Abrogation of Articles 370 and $35 \mathrm{~A}$ of the Indian Constitution}

On 4 August 2019, BJP led government took harsh steps against people of Kashmir and phones in the valley went dead and internet connections were cut. Life was completely blocked and strict military curfew was imposed on people. On 5 August, thousands of 
people from young children to teenage were arrested and put into preventive detention. On 6 August, a bill was passed in parliament and it had damaged the autonomy of state of Jammu and Kashmir and its special status preserved in the constitution of India. ( $B B C$ News, 2020).On 4 August 2019, BJP led government took harsh steps against people of Kashmir and phones in the valley went dead and internet connections were cut. The state was demoted into two union territories named as Ladakh and Jammu and Kashmir. It was decided that Ladakh would have no legislature and would be controlled directly by New Delhi. It was political and ideological agenda of Bharatiya Janata Party to remove the special status of Jammu and Kashmir and merge it into Indian Territory. It was also clearly mentioned in the manifesto of BJP's 2019 Lok Sabha Election "abrogation" of Article 370 and the annulment of Article 35A, which allowed the J\&K legislature to define permanent residents of the state" (BBC News,2019).

After this Modi's action everybody came to know about the real designs and intentions of BJP-led Hindu nationalist government. Former CM Mahbooba Mufti told the BBC after the act of annexation of Jammu \& Kashmir by Narendra Modi: "They just want to occupy our land and want to make this Muslim-majority state like any other state and reduce us to a minority and disempowered us totally." (BBC News, 2019).

From Farooq Abdullah to Ms. Mehboba Mufti who wants complete emancipation of Kashmiri people now got idea that how it feels to live under a cruel and oppressive regime of Modi (Khokhar, 2019).

\section{The Jammu and Kashmir Reorganization Act 2019}

The main purpose of Jammu and Kashmir Reorganization Act 2019 is that to hold great control over the Kashmiri people and on their local and administrative affairs. (Loc, 2019).BJP took this step to get more legislative powers in J\&K in addition to control the police and defense of public order. The decision of quick implementation of reorganization Act 2019 after repealing special status of J\&K's and BJP was anticipating violent civilian protest and unrest among people in the Kashmir Valley. So, it wanted to control all such situation immediately. Nevertheless, Indian Home Minister Amit Shah guaranteed the parliament that when the situation came back to normal and "the right time comes," the central government will once again grant full "state" status to the union territory of J\&K" (Sharma, 2019).

\section{Indian Citizenship Amendment Act 2019}

On December, 2019 controversial bill was passed in the parliament of India. The bill grants nationality to victimized communities of Hindus, Sikhs, Buddhists, Jains, Parsis and Christians who moved towards Pakistan, Bangladesh and Afghanistan. This is considered as extremist action and fascist measures of the Bharatiya Janata Party to impose Hindutva ideology and to convert Muslim majority into minority specifically in Kashmir so that Muslims can face brunt of persecution. (Rasool, 2019).People all over India gave violent response through demonstrations towards this bill. As protesters stated that it would convert thousands of illegal immigrants into legal residents. According to renowned historian Mukul Kesavanthe bill is "couched in the language of refuge and seemingly directed at foreigners, but its main purpose is the delegitimization of Muslims' citizenship". (BBC News, 2019). 
Communal hatred is in the manifestation of RSS and as a member of this organization Modi is promoting this and creating disturbance in Muslim communities. Modi under his BJP government wanted to expand Hindutva by adding Hindus and excluding Muslims from all over India and In Kashmir. This action of BJP government is against its spirit of democracy and secularism that mentions in the Indian constitution. (Roy, 2009).

\section{Political Impact of Modi's act of Removal of Jammu and Kashmir Special Status}

There are several possible political implications of the decision of BJP government to abrogate Article 370 and 35A. (ORF, 2020).Firstly, Indian government may now be able to hold strong control over Kashmir and would claim that the issue of Kashmir is "internal" matter of India and then no third party is required for mediation. Secondly, this issue has created possible civilian unrest and has increased terror attacks in the Valley which is raising conflicts between the government of India and Pakistan as Pakistan also claim its hold over Kashmir valley due to majority of Muslims communities resides over there. Thirdly, all such contentious policies of Modi have closed all the doors for bilateral talks between India and Pakistan for the resolution of Kashmir issue. Fourthly, Kashmiri will abide by Indian constitution and they have to surrender their constitutional power before Indian government. People from outside the Kashmir region now can live there and can buy property or land. According to BJP these steps will bring prosperity into the region but if we deeply analyze its policies we came to know that this action has been taken for getting numeric advantage in the next elections of 2024 by opening this land for Hindu majorities and by adding this territory into Indian Union (Sharma, 2019).

\section{Modi's Ideology: Biggest threat to Regional Peace}

After the revocation of special status of Jammu and Kashmir and India's effort to merge J\&K into Indian union is widening dispute between two nuclear states between Pakistan and India and it has now become threat for regional peace and stability because both these states claim their sovereignty over Jammu and Kashmir.(Akbar, 2020). Since the independence of Pakistan, both India and Pakistan have fought two wars in the year 1948, 1965 over Kashmir issue. Several Kashmiri liberation groups in Jammu and Kashmir have been fighting against Indian government rule for emancipation. Conflict in Kashmir due to the Indian fascism is creating serious threat to peace and stability in the region. (Times, 2020).Indian occupational forces are doing harm and physical tortures to the people, the ideology of Hindutava under Modi government is becoming a threat to neighboring states. Modi fascist government is damaging the identity of minorities of India as it is converting them into second class citizens therefore; frustration among citizens is a threat to regional peace. Illegal annexation of IIOJK by Modi government which had put the peace of South Asia at stake. India wanted to establish its hegemony over South Asia has always created instability in the region (Akbar, 2020).

\section{Future Prospects}

BJP government under the leadership of Modi is a perfect illustration of promoting fascism in Kashmir. The concept of largest democracy of India is dooming under Modi's BJP government because he is militarizing the civil society so that he can stop their voices for liberation and against his brutal rule. Violence in the valley due to illegal actions of BJP government is the most significant indicator that their behaviors are authoritarian and 
projecting fascism to fulfill their Hindutva ideology.(Bose, Jalal, 2021). Communal violence under BJP government has been widened in Kashmir after the introduction of its controversial policies. Fascist ideology and policies of Modi are making him direct descendants of Hitler and Mussolini. According to renowned writer Arundhati Roy, BJP fascist policies danger will come in the Jammu and Kashmir from many directions because far-right Hindu Nationalist organization RSS which has almost 6000,000 members in which most of the ministers of BJP and Modi is giving training to volunteer militias who are inspired by Mussolini's Black shirts. (Roy,2020). As Black shirts are most distinguished uniform of Fascist organization in Italy it seems that BJP has got legal power under RSS to create violence against Muslims and Dalit and to tore the social fabric of J \& k. These kinds of policies and actions by BJP will not only increase danger in Indian Occupied Kashmir but also has potential to create instability inthe South Asian region. (Akbar,2020). More than one year has passed to the arbitrary abrogation of Article 370 and $35 \mathrm{~A}$ of the Indian Constitution the situation has become worst by continuous violation of ceasefire by Indian troops, cross border firing of Indian troops on innocent civilian population on Pakistani side of the border. If India under Modi will continue its fascist agenda the situation can become more dreadful for India and Pakistan in future (Roy, 2020).

\section{Conclusion}

India has become a hypocrite state because it uses the name of democratic principles but in actual terms it is promoting fascist ideology under the leadership of Modi. BJP led government has done so much injustice in Kashmir by the enforcement of illegal and controversial laws in Jammu and Kashmir. To hold regular elections in Kashmir cannot provide justification to the Indian government that it is following Democratic principles. The blatantly rigged elections in the region and Indian military occupation clearly rejected Indian claim of democratic country. Revocation of Jammu and Kashmir special status by violating Article 370 and Indian organization act are not less to glorify Modi Fascism in Kashmir. Article 35A which provides legal security to Kashmiri people that they can live freely but its dissolution means to make the minority in their own territory where they are in majority and Kashmir "being open for business" means territory is open for Israeli-style settlements and population transfers in Tiberan-style. Naredra Modi's fascism is creating violence in Kashmir and it has become a threat to peace for Pakistan as well. Both have launched airstrikes against each other after august 4 illegal actions by Modi. No one dare to speak about the fascist ideology and atrocities of BJP government in Kashmir. The world has to stand for the protection of human rights and should talk about curfew in the valley, illegal mass arrests and lockdown as it is the sheer violation of human rights. However, Indian cannot fool all the people all the time, its short term solution is just adding fuel to fire and creating unrest in Kashmir. Kashmir dispute can only be resolve on humanitarian basis. To stop Modi fascism negotiations will have to be prepared between India and Pakistan deviate from the ideology of one party and solution should purely base on the best interest of Kashmiri people and it is only possible if India admit their right of selfdetermination according to UN resolution. As BJP does not have mandate of Kashmiri people and their support to pass through the Hindutva projects.

\section{Recommendations}

Kashmir which is the long standing issue between India and Pakistan can only be resolved on humanitarian basis. India is trying to merge Jammu and Kashmir into Indian 
Union should be stopped by International community forcefully. It is the responsibility of UNO to hold plebiscite under its own supervision in Jammu and Kashmir and then decide the solution of Kashmir dispute. Pro Indian states in UNO should understand that this issue has potential to destroy the peace of world so they have to play their role to cease the illegal activates of Modi led Indian government in Jammu and Kashmir. World powers can block off the actions of Modi in Kashmir valley for violating the International humanitarian law. 


\section{References}

Akbar, M. (2020). Rising Fascism in India: Case Study of Modi's Regime. Journal of Indian Studies, 6(2), 273-284.

Bhat, S. A. (2019). The Kashmir conflict and human rights. Race \& Class, 61(1), 77-86.

Bhatty, K., \& Sundar, N. (2020). Sliding from majoritarianism toward fascism: Educating India under the Modi regime. International Sociology, 35(6), 632-650.

Bose, S., \& Jalal, A. (Eds.). (2020). Kashmir and the Future of South Asia. Routledge.

Cheema, M. J. (2020). Pakistan-India conflict with special reference to Kashmir. South Asian Studies, 30(1).

Cohen, S. P. (2002). India, Pakistan and Kashmir. Journal of Strategic Studies, 25(4), 32-60.

Desai, R. (2016). Hindutva and fascism. Economic and Political Weekly, 51(53), 20-24.

Farooq, S., \& Gul, S. (2020). From Pulwama to Indian Revocation of Article 370 in Indian Held Kashmir: Policy implications on the Geopolitics of South Asia. Global Legal Studies Review, V(I), 8-14.

Iqbal, A. C. R. K. (2019). India's Crumbling Kashmir Narrative. Pakistan Observer.

Islam, S. RSS: Marketing Fascism as Hindutva. National Volunteer Association, Hindustan Times, New Delhi, March 21, 2002.

Khan, K., \& Cheema, P. I. (2017). Modi's Kashmir Policy. Strategic Studies, 37(3), 1-21.

Kohli, R. (1993). Political Ideas of MS Golwalkar: Hindutva, Nationalism, Secularism. Deep and Deep Publications.

Masood, H. Sultana, M. \& Muzaffar, M. (2020). No Modus Operandi for Seeking Solution to Liberate Kashmiri Muslims, Pakistan Social Sciences Review, Vol 3 Issue II, 268-281

Paswal, N. H., Jafri, S. I. H., \& Fatima, S. Historical Analysis of the Abrogation of Article 370.

Riddell, J. (2019). Kashmir crackdown poses risk of war. Green Left Weekly, (1233), 14.

Roy, A. (2009). Listening to grasshoppers: Field notes on democracy. Penguin UK.

Roy, A. (2020). Azaadi: Freedom. Fascism. Fiction. Penguin Random House India Private Limited.

Roy, A., Mishra, P., Bhatt, H., Chatterji, A. P., \& Ali, T. (2011). Kashmir: The case for freedom. Verso Books.

Sarkar, S. (1993). The fascism of the Sangh Parivar. Economic and Political Weekly, 163167. 
Selvi, K. M. (2019).The Bullied and The Bought: Arundhati Roy's Contentions in the Shape of the Beast. Literary Endeavour, 20.(ISSN 0976-299X).

Shah,K.M Shah.K.(2020).Kashmir After Article 370: India's Diplomatic Challenge, Observer Research Foundation.

Sharma, S. (2019). The Political Impact of India's Removal of Jammu and Kashmir's Special Status. South Asian Voices.

Simeon, D. (2013). The Law of Killing: A Brief History of Indian Fascism. Banaji (ed.), 153213.

Sinha, S. (2021). 'Strong leaders', authoritarian populism and Indian developmentalism: The Modi moment in historical context. Geoforum. 